\title{
Development models and strategy of micro, small and medium enterprises (MSMES) in South Sulawesi
}

\author{
M.A. Ardiansyah ${ }^{1, *}$ \\ ${ }^{1}$ Department of Economics, Faculty of Economics Andi Djemma University, Indonesia \\ *Corresponding author: muh.awalardiansyah@gmail.com
}

\section{ABSTRACT}

The objective of this research is to understand the purpose of the authorities, banking, and abuser of Micro, Small and Medium Enterprises (MSMEs). Business organizations, community leaders, in the building of SMEs development strategy. The research uses Phenomenology method by understanding the perspectives of ethics and interpret the disclosure of informants involved in this research. The unit of analysis in this research are: individual businessmen of MSMEs in the food and beverage industry, individual local government officials from the Department of Industry, cooperatives and regional SME research, individual figures of Individual regions, the business banking officials and individuals representing community leaders who understand the problem of MSMEs. The theoretical framework has been drawn out and questionnaire was designed based on the factors chosen. Findings of this research are useful for member access to capital, access technology, and the market for MSMEs, The local government must establish a credit guarantee institutions, build partnerships with banks, State-Owned Enterprises, large companies, commerce, cooperatives, universities and non-governmental organizations (NGOs). In addition to the member's access for marketing, the local government should provide a joint marketing Center for MSMEs in the form of an outlet. Absolute protection against MSMEs so the local government can develop an ongoing basis. In order to develop MSMEs particularly engaged in the food industry, the local government should build the development strategies in the form of partnership between large and MSMEs entrepreneurs with all stakeholders in the area of South Sulawesi.

Keywords - Strategy, Development, MSMEs, Models, Partnerhip

\section{INTRODUCTION}

Small and medium business is a strategic asset for development, which can create huge job opportunities, i.e. in 2013 can absorb 99, 45\% labor and created value added to GDP of 58, 3\%. A very large Micro, Small and Medium Enterprises (MSMEs) contribute to the absorption of the work force, but on the other hand is still have small contribution in providing value added to GDP. This is as a result of the discrepancy between the MSMEs work productivity with great effort, in addition the growth of SMES is faster compared to the large business group will improve business and income distribution structure as a whole. Thus, if MSMEs were the backbone of the economy, the increase in the productivity of SMES should be the central economic policy in times to come (Ikhsan, 2004: 14). In the phenomenal success of MSMEs in absorbing the labor and contributions to GDP in some countries, indicating a condition different from conditions that occur in Indonesia. Micro, Small and Medium Enterprises (MSMEs) in developed countries are able to contribute to the provision of job opportunities and a high GDP, as experienced by Singapore, MSMEs were able to push economic growth higher to occupy a second position only to the United States. In South Sulawesi, the MSMEs is very potential and play an important role in this endeavor which can provide the right opportunity to earn income, especially for women and the weak economy that existed in South Sulawesi. It is important to understand that total of MSMEs existing business in South Sulawesi was $98,83 \%$ by business classification include: micro 87,60 \%, small businesses, medium businesses $11,62 \% 0.60 \%$ and 0.17 percent of Large Businesses (BPS: 2012). Such a huge proportion of the SMEC $(98,83 \%)$ in South Sulawesi that society in general are still at the MSMES business scale and its tendency is at the micro (household enterprises) which amounted to $87,60 \%$. The population of business units 
with a total of micro is dominated by efforts in agriculture, services and industry. The emphasis in particular on shape selection of priorities, operational forms are specifically done to encourage the success of SMES in using comparison own excellence. The first study carried out in Singapore to develop an operational strategy the SME classification basing on the principle of high business performance. Research conducted by selecting three different types of clusters to be identified. Apparently the result of identification shows that there is a real difference in each cluster in the form of operations such as; financial performance, and a range of performance improvement program within the cluster. Hak-Su (2005), declares that the community's attention to Asia and the Pacific (UNESCAP) towards the empowerment of SMES through the options strategy that is considered important, with considerations: (1) SME business is a model of transition to large corporations, (2) SMES can create large employment opportunities and (3) the SMES directly giving the role to the economic growth of a country or region. Other than small and medium enterprises are embryos that could be developed of expanding their operations to become a large company in the long term.

The cornerstone of empowerment of MSMES can be reflected in the five principles of empowerment, namely: (1) Empowerment MSMEs based on the growth of entrepreneurial independence and attitude to work with its own initiatives and competitive power, (2) Empowerment MSMEs was carried out with the support of public policies that are transparent, accountable, and non-discriminatory, ( either between the offender, sectors regions, and gender) which can facilitate MSMEs in running his business and access to productive resources, (3) Empowerment of MSMEs oriented on the development of market-based, global development with anticipation, and protection against fraudulent business practices, (4) Empowerment of MSMES was carried out with more emphasis to a systematic and sustainable process that is capable of supporting the growth of MSMES and competitive superior and (5) Policies, programs and plans for follow up activities, empowerment of MSMEs built through consensus or agreement among all stakeholders, which include; Local governments, non-local governmental organizations, and related community. The strategy in fact is a common action plan, long-term (oriented to the future), and its coverage area. Therefore, strategies are typically formulated in sentences, meaning the content is very common and does not refer to specific actions or details. Nevertheless in strategic planning does not mean that "detailed and specific action" which is usually encapsulated in a work program should not be compiled. Otherwise the work programmers should be planned also in the strategic planning process and should even be formulated or defined measure of performance.

\section{METHOD}

This research uses qualitative approach to select the perspective of Phenomenology as an approach. Phenomenology used in this research which intended to express the meaning of a reality going on in a situation and context where do, through the speech and behavior of human beings or subjects in the study of what is done and said and experienced. The position of methodology of Phenomenology and distinguish it from quantitative research with the aim of: (1) Unearth the values in human life or experience, (2) To find the meaning and the nature of the experience, not just looking for an explanation or look for reality, (3) To obtain an overview of life from the perspective of the first person through formal and informal interviews and (4) Statements were made reflecting the interests, involvement and personal commitment of researchers (Kuswarno 2009: 36).

The data and information obtained through information gathering, then analyzed using qualitative analysis. Qualitative analysis is designed to understand an object or subject through the disclosure of what is seen, felt, and experienced within the context and situations where conducting data collection. Data analysis on qualitative research is shaped cycle and not linear as can be seen in Figure 1 below:

\section{Figure 1. Research Process}

\section{RESULTS}

Comparative data analysis is intended to compare the information obtained from different sources, as emphasized in the Triangular model so the information can be sourced from various corners in the photograph a phenomenon to find a nominal (the reality) of the definition of the understanding of the informant (EMIC) and understanding research (ethics).

a. Understanding the informant to the problem of MSMEs in Difficulties of access to capital at a formal financial institutions. 
The selection strategy in the development of MSMEs, became a very basic problem because the chosen strategy into a hope for the entire party will be able to make the MSMEs. At this moment MSMEs still haven't been able to play a role as well in encouraging economic growth and reduced income inequality among groups of business in Indonesia. One of the reasons is the limitation of access to formal financing institutions in the capital such as banks due to conditions of MSMEs, especially small and micro enterprises generally bankable by rating the banking. Therefore, it becomes difficult for accessing capital on a formal institution although it is known that the local government already provides joint financing of MSMEs in the form of a credit to the people (KUR) with a very soft terms, without collateral being guaranteed by the local government. Understanding individual informant which represents the local government in the matter of the office of cooperatives and SMEs. In this case represented by Drs. Abd. Azis Bennu, D. M. who stated that: "Strategy as an effort to help the perpetrators of micro enterprises small in order to be successful" local government should seriously provide financing assistance nature where easier for the principals of MSMEs since the current financing for MSMEs is not yet accessible for good so that MSMEs still facing difficulties in terms of capital already exists in many forms, one of these is the KUR, however MSMEs still have trouble.

\section{b. Understanding the informant to the problem of MSMEs in difficulties of access technology.}

Technology becomes a vital necessity for businessmen in pushing the development of his business, as with the main application of technology in production, can help the MSMEs improving the quality and quantity of the products. The problem is not all the MSMEs can easily access the technology in the general businessmen especially micro enterprises of very low quality of education in General graduate elementary to admin, and only a few educated scholar. HR education trade conditions of low influence on the mindset and for them in the conduct of business, so in general businessmen working in accordance with his wishes and not on market orientation. As a result the effort for that resulting product is very low quality and cannot compete with other businesses that are already using adequate technology. Obstacles for businessmen of MSMEs in technology is still lacking availability of official institutions in both the private sector and local government circles that provides mentoring and guidance to business various technologies related to ease of production. They are still limited to attend training because the cost is extremely limited.

\section{c. Understanding the informant against the difficulties of MSMEs in market access}

A major problem is faced by entrepreneurs of MSMEs after generating stuff is marketing, because items generated by this business group have also been generated by large corporations that increasingly gets pressure in marketing. The quality of industrial products tend have better quality than the products of MSMEs. As delivered by "Drs. Abd. Azis Bennu, MM "the market for MSMEs primarily small micro enterprises are still very limited because the resulting product does not yet have quality standards and makes it harder to compete in the market. Similarly with interviews of Mr. "A. Matentuang, MM", he was one of the informants represented public figures reveal: that generally MSMES face major problems on a lack of access to capital and markets, making it difficult to develop goods, therefore if the MSMEs want to develop the key only to capital and a variety of markets.

\section{DISCUSSION}

The Interpretation of the results of the informants' interviews in search of MSMEs development strategy building.

An understanding of strategy in developing of MSMEs, has many meanings depend on the target and what will be achieved. Surely any strategy is rare that can deliver a plan to achieve the results planned beforehand, so that inside the building a strategy of MSMEs. First examine the meanings associated with the actual condition and the crucial faced by MSMEs but in this study looked at the actual problems which have three crucial to overcome such as access to capital formal (bank), access to market and access to technology through training and mentoring. The strategy will be implemented through is expected to help the perpetrators of MSMEs in handling with the problem, so the MSMEs can grow and develop as a strong, independent MSMEs and can compete both local as well as national and even global. Based on the results of the disclosure of the informant from various backgrounds, then do approach based on the definition of the Phenomenology, to gain meaning from a number of disclosure or information not by informants, but it can be captured this research object side tie (MSMEs). In addition carried out searches of documents, the literature 
research results (triangular) and hope to not make these findings are subjective, so that results of research possess: confidence level (credibility), (transferability), reliance (dependability) and certainty (conformability).

Access technology strategy development through training and mentoring, examined from the view of informants. MSMEs access to technology in general is still something that is hard to do, given the capability of MSMEs offender average is still very limited. Their limitations in addition to the level of education as well as the limited access to related information technology. They run his business running is appropriate capabilities so that their production results sometimes face problems, both in terms of volume and quality. Technology can be accessed through training and mentoring done by local government or non-local governmental institutions such as the center of the business incubator center, empowerment and development program a college entrepreneurship. However, access to MSMEs up to the institutions of the mentorship and training providers is not as easy as it is to be made by most businessmen, only those who have a line that can be accessed training and mentoring. Mentoring and training activities conducted by the local government so far is still considered limited in the number of MSMEs serve many. On the other hand, the abilities to do training with constrained resources, funding sources and support facilities. It can be understood from the meaning of the results of the analysis of the utterance informant, as expressed by "Martin.U B" that many programs in the framework of the application of technology to business (MSMEs) actors, but the agencies face in financing programs such as training courses conducted so far from what was expected at this time. Therefore it is expected that for the future the local government should make the MSMEs development strategy planning more effective and clear learning outcomes-oriented rather than just the product. "Training activities carried out so far by local government agencies have not been able to meet the needs of MSMEs effectively so impressed that the training benefits small.

It is expected to all local governments in making MSMEs development strategy. Also they should consider more mature about: access to capital, access to technologist and market access. What will be done in the next plan should be formulated in development strategies which made so great a benefit for MSMEs. The local government in building a strategic plan of development of MSMEs, preferably involving colleges and non-local governmental organizations that have in the field of development of MSMEs, because without the support, the local government will faced the difficulties in member training services for businessmen. The local government is also expected to encouraged state-owned enterprises, local government, commerce and big corporations that exist in this area to partake in training activities in increasing the capability of access to technology. Build partnerships between small businesses with great effort, is also a strategy that should be considered in making the plan of development strategy of MSMEs. Partnerships can be effective in technology transfer and transform from large companies to small companies. In addition the cost can be reduce due to the partnerships that are interwoven.

Large companies:, state-owned enterprises, Local government, play an important role in CSR through capital member and the member's access to training in technology transfer. Banking, capital assistance the role of the member, through CSR, or partners who the local government through intermediaries. College has a role in providing training, mentoring through outreach and training centers and, business/entrepreneurial Incubator through. Indeed commerce and other business have a great role to mediate the perpetrator of MSMEs with great effort in the form of a partner and adopted son, member training facilities in technology transfer. Cooperatives and MFIs, had a role in bringing perpetrators of MSMEs become cooperative members to ease access to credit as well as micro finance institution (MFI). Non-governmental organizations play a role in mentoring and training members in the framework of technology transfer.

\section{Figure 2. The Model and Strategy for Developing the MSMEs in South Sulawesi}

\section{CONCLUDING REMARK}

For the conclusion, the investigation results analysis of this study disclosure of the informant from many quarters, found the meaning that to encourage the development of MSMEs in times to come, then protection of MSMEs should be done by the Local government through partnerships between micro, small and medium enterprises with great entrepreneurs, banking, commerce, local government, state-owned enterprises, high education, cooperatives MFIs and NGOs, for both role and structured pattern in partnerships. Therefore resolve the fundamental problem faced by MSMEs such as access to capital, access to technology, and market access. By building partnership, 
expected patterns of all stakeholders can play a role in accordance with its capacity, so that the issues that inflates local government in faced of MSMEs can be resolved on an ongoing basis so that the MSMEs into thriving and powerful.

\section{ACKNOWLEDGEMENT}

I would like to thank Ardi, Muhammad for his comments and suggestions regarding the analysis. I also would like to thank Marsus S. Halid, Irman and Sadio, Kamilah for fruitful discussion as well as their supports and encouragement. This research was conducted for local government of South Sulawesi in particular for Palopo Local government at Andi Djemma University.

\section{REFERENCE}

Alina B. Hyz. 2011. Small and Medium Enterprises (SMEs) in Greece - Barriers in Access to Banking Services. An Empirical Investigation. International Journal of Business and Social Science Vol. 2 No. 2; February 2011

Angela Roman, A. and Valentina Diana Rusu. 2012. The Access of Small and Medium Size Enterprises to Banking Financing and Current Challanges: The Case of EU Countries. Annales Universitatis Apulensis Series Oeconomica, 14(2).

Basrowi dan Sudikin. 2002. Metode Penelitian Kualitatif Perspektif Mikro. Penerbit Insan Cendekia Surabaya.

Bungin, Burhan. 2003. Metodologi Penelitian Kualitatif "Aktualisasi Metodologis Ke Arah Ragam Varian Kontemporer. PT. Raja Grafindo Persada Jakarta.

Djumilah. 2002. Membangun Ketahanan Ekonomi Indonesia Melalui Pemberdayaan Ekonomi Rakyat. Penerbit Universitas Sarjanawinyata Tamansiswa.

Gangata, Kendra and Ephraim Hudson M.M. 2013. Challenges facing SMEs in accessing finance from financial institutions: The case of
Bulawayo, Zimbabwe. International Journal of Applied Research and Studies (iJARS) ISSN: 2278-9480 Volume 2, Issue 7 (July- 2013) www.ijars.in

Ghana Banking Survey. 2013. Harnessing The Small and Medium Enterprises. A. Message From The Executive Secretary of Ghana Association of Bankers.

Kotler, Philip Dan Amstrong, Gary. 2009. PrinsipPrinsip Pemasaran, Jilid I Edisi Kedelapan. Erlangga. Jakartaim Hak-Su. 2005. Key Challenges For SMEs Development in Asia and The Facific and to Bring Six Strategic Choices to Your Attention. UNESCAP.

Kim-sum. . 2005. Key Callenges For SMEs Develovelopment in Asia and The Fasific and to Bring Six Srategic Choices to Your Attention. UNESCAP.

Krisnamurthi B. 2003. Usaha Mikro, Kecil Dan Menengah: "Ekonomi Rakyat Dengan Cara Berekonomi Mereka Sendiri", Disampaikan pada Kongres XV ISEI, Malang Jawa Timur

Lau GeokTheng and Jasmine Lim Wang Boom. 1996. An Exploratory Study Of Faktors Affecting The Failure Of Local Small And Medium Enterprises. "The potential Contribution of Local Small and Medium Enterprises to Wards Employment and Grwth in Singapore". Asia Pasific Journal of Management; Oct 1996; 13,2; ABI/INFORM Research.Mambula .C and Frank E. Sawyer. 2004. Acts Of Enterpreneurial Creativity For Business Growth and Survival in A Constrained Economy "Case Study Of A Small Manufacturing Firm (SMF)". International Journal of Social Economics; 2004; 31, 1/2; ABI/INFORM Research.

Tee Kian Wie. 2004. Pembangunan, Kebebasan, dan Mukjizat Orde Baru. Penerbit Buku Kompas. Jakarta.

Yunus, Muhammad. 2007. Bank Kaum Miskin " Kisah Yunus dan Gramenn Bank Memerangi Kemiskinan”.
Figure 1. Research Process

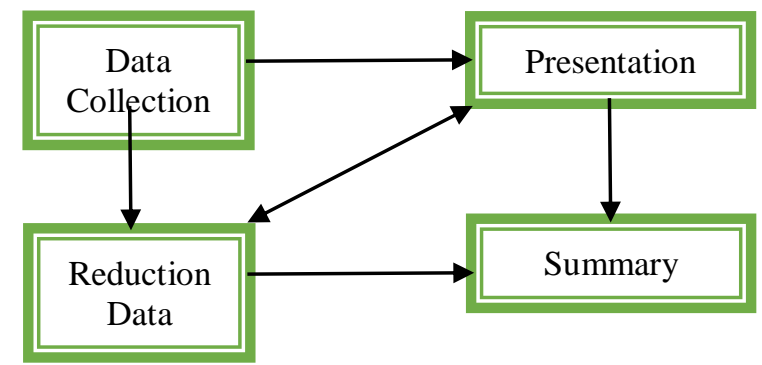


Figure 2. The Model and Strategy for Developing the MSMEs in South Sulawesi

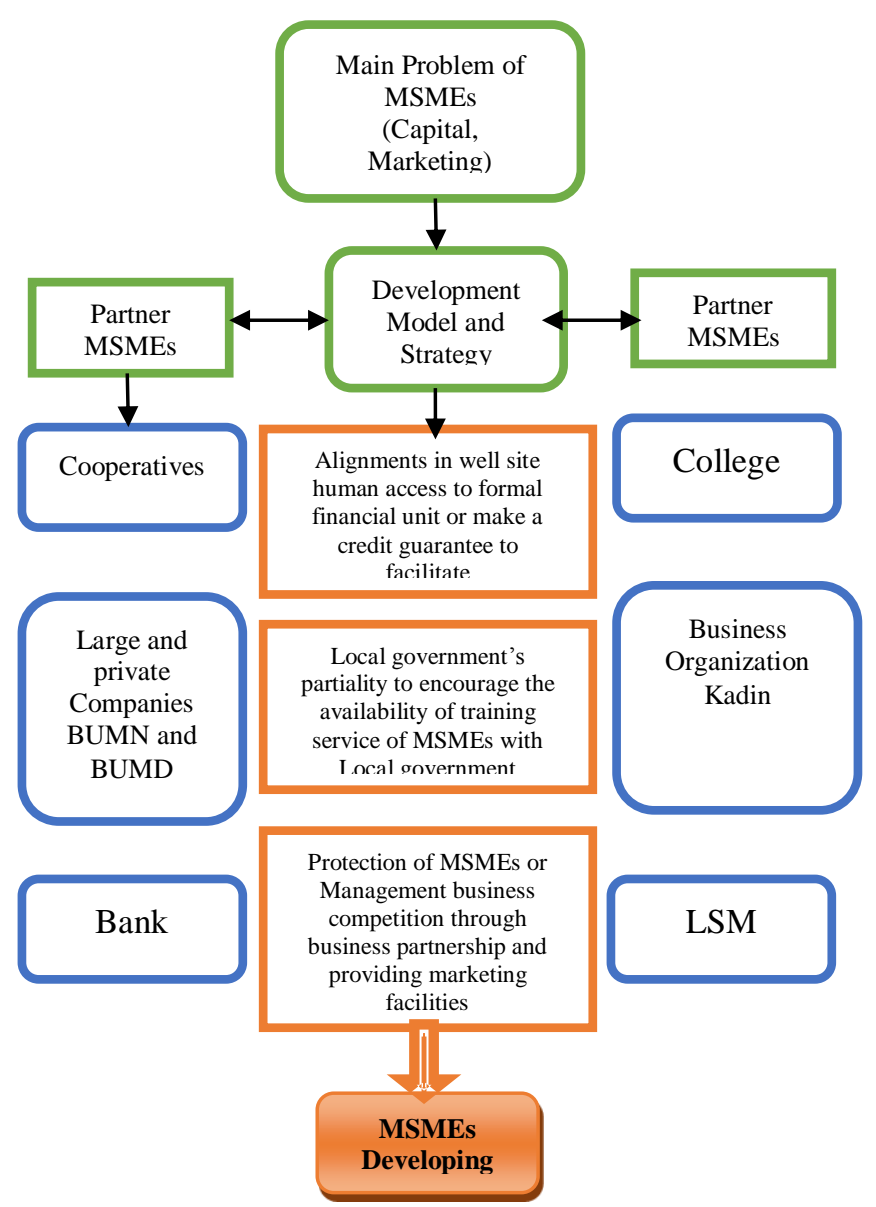

